\title{
Philosophy and Practice in Translational Hermeneutics edited by J. Stanley, B. 0’Keeffe, R. Stolze, L. Cercel Bucharest: Zeta Books, 2018, pp. 398
}

Translational Hermeneutics, as a relatively young subdiscipline of Translation Studies, has not yet gained much popularity across the globe, in particular among a great deal of translation scholars who tend to criticize the approach for its vague, metaphorical lexicon, the unresolved question of the connection between objectivity and subjectivity, and for a lack of empirical studies which could confirm the tentative assumptions that are made by translational hermeneutists with regard to the translator's status as a central figure in the translational process. As the authors of the edited collection titled Philosophy and Practice in Translational Hermeneutics rightly accentuate:

There is a significant level of distrust of hermeneutics in fields dominated by the empirical approach to research, for instance, but also in the humanities. It is partly matter of the difficulty that obtains when one asks whether hermeneutics (especially if one describes it as an effort to 'understand understanding') has any specificity to it: does hermeneutics understand things better, or differently (and in a valuably different way) compared to other approaches to interpretation, or to what one might venture to describe as interpretation in general? It is partly a matter of the philosophical tradition in which hermeneutics is situated. Here there is a certain specificity, to be sure (and we can call that specificity 'philosophy,' quite simply), but if interpretation, and translation, are ultimately practical undertakings, do the abstractions and conceptual frameworks of philosophical hermeneutics hamper or assist in gaining a better understanding of such practices? (2018: 7)

At the same time, though, it has to be underlined that an increasing number of researchers working within literary studies, linguistics, communication and media studies, philosophy, sociology and translatology, amongst others, discover their mutual interest in the reciprocal relation- 
ship between philosophy and translation, with a special emphasis on how translation might relate to hermeneutics, and to what extent issues explored by hermeneutists might be exploited in the area of Translation Studies. Without too gross an exaggeration, it might be tentatively concluded that all those scholars struggle to find an answer to the questions presented in the closing part of the quotation above. And as it seems, this is also undoubtedly the question which remains of the utmost importance to the authors of the papers presented in the reviewed collection. What should also be added with regard to the above is that finding a proper solution to the problem concerning the interplay between very abstract ideas as contained in Gadamer's, Heidegger's or Ricoeur's works, to name but a few, and quite concrete and more tangible concepts as illustrated by the current needs diagnosed within the translational didactics paradigm will surely determine the future of the now developing Translational Hermeneutics.

The book titled Philosophy and Practice in Translational Hermeneutics, an outcome of the Second Conference on Hermeneutics and Translation Studies held in 2013 in Cologne, comprises a collection of fourteen essays, which might be divided into two complementary themes. The first group of texts revolves around philosophical approaches to translation, including Gadamerian philosophical hermeneutics, Husserlian phenomenology, as well as rhetorical, social and semiotic aspects of translation, whereas the second set of essays has more to do with broadly defined practice. Within this second collection of articles a reader will discover very interesting examples and comments on the use of hermeneutical and phenomenological methods and techniques which could be successfully applied in translation pedagogy, as well as texts in which their authors attempt to analyse specific literary samples, including children's literature, with relation to their translations.

With regard to the above, it is worth clarifying to what Translational Hermeneutics is usually referred and in what way it is understood by the editors of the reviewed volume. First of all, however, we should focus on a short history of this approach. The category of translation, it seems, has always been fundamentally important to those philosophers who took a keen interest in the interplay of ideas encompassing the issues of meaning, interpretation, language and understanding. It is, in particular, worth mentioning Schleiermacher, Dilthey, Heidegger, Gadamer and Ricoeur, to name but a few main representatives of so-called continental philosophy who established the more or less systematic locus of translation within their areas of interest. Besides, one has to firmly acknowledge that when Gadamer's magnum opus was published, in which the philosopher elaborated the problem of translation by extending it to the universal problem of human understanding and the truth of hermeneutic consciousness (for more see Gadamer 1972: 259), Translation Studies as we know it today was still in its infancy. In that respect, it might be assumed that the hermeneutic approach to translation, deeply embedded in the philosophical tradition, is probably the oldest systematic thought given to the issue of translation. As it seems, Gadamer's views on translation gave rise to the contemporary line of reasoning exhibited by translational hermeneutists, that is, scholars who by referring to the fundamentals of philosophical hermeneutics aspire to determine the scope within which hermeneutics might be productive and fruitful for Translation Studies, 
and in what way the analysis of the category of translation might enrich hermeneutics as a philosophical line of thought dealing with human actions and their diverse implications for the reality in which those actions are performed.

Gadamer was a deep source of inspiration not only for other philosophers, for instance Paul Ricoeur or George Steiner, but also for scholars concerned with translation from a philological standpoint. One of them was Fritz Paepcke - the father of contemporary hermeneutic theories of translation (for more see Cercel 2009: 331-357), who, in turn, inspired his student, Radegundis Stolze, to pursue the hermeneutic approach to translation (see Stolze 1992, 2003, 2011, 2015). Despite those very important attempts to place the hermeneutic approach to translation in the visible arena of the then developing Translation Studies, it seems that it was not until 2009 that Translational Hermeneutics per se started to gain impetus, which might be a bit surprising given the fact that a wide variety of issues tackled by representatives of the hermeneutic approach to translation are more or less on a par with those which were examined by vocal proponents of the so called translational turns: cultural, ethical or sociological, to name only a few. Perhaps the reason for this marginalization of hermeneutics within Translation Studies might be partially attributed to new roadmaps for the advancement of Translation Studies which started developing in the 1980s. What I mean here is, above all, the so called empirical turn and the dominance of the method (here TAPs, retrospection, and later eye-tracking methodology, key logging or even EEg and fMRI, among others) from which Gadamer and other philosophers taking a hermeneutic standpoint distanced themselves. Such a critical approach to the hermeneutic approach to translation, however, might be surprising, because - as Andrzej Bronk, one of the best known among Polish authors commenting on Gadamerian philosophical hermeneutics, underlines - what hermeneutists claim is by no means contradictory to the most demanding ethos of science (1988: 64). Additionally, the reason for the negligence of Translational Hermeneutics within Translation Studies might be the dominance of the English language in contemporary translational research and its connection to analytic philosophy, where hermeneutics has always been struggling for its position.

Let us, however, return now to the clarification of the term Translational Hermeneutics. According to Larisa Cercel, it is a line of reasoning which places the issue of understanding in the translation act at the very heart of interest, as well as subjective and intersubjective relations between the issues (2013: 16). What is crucial, though, is that it is not the text per se that has immense significance for proponents of Translational Hermeneutics, but rather the translator - referred to as a central figure in the translation process - and their relations with both themselves and other agents of the translation act (authors of the source texts, prospective readers, narrators, protagonists), as well as with the cultural and social conditions in which the translator is inextricably embedded. What translational hermeneutists are particularly interested in is what it means to understand and interpret the source text and how it is possible that translation could be produced at all. Looking at the considerations above, one might assume that the entire paradigm of Translational Hermeneutics is not that different from what other translatologists, representing various movements and turns within Translation Studies claim; what is missing, though, in all the differ- 
ent approaches to translation, including cultural, social, ethical, psychological or empirical turns, is, first of all, the way the translator aspires to understand their agency and practice as juxtaposed against the backdrop of the notion of intersubjectivity, and secondly, the way translation itself is understood (here as both linguistic and non-linguistic expressions of a human's relation, and interrelation, with the world).

The first theme around which some of the articles of the reviewed volume revolve is titled Philosophical Approaches. Let us follow all the texts one by one because their order, as will be shown later in this part of the review, is by no means accidental. Starting with the notion of the embedment of translation in philosophical traditions, and its implications for the mental processes involved in the act of rendering, including specialized translation, this first part of the monograph moves through translation as seen through the lens of semiotics, rhetoric, social system theories and hermeneutics - approaches which, in one way or another, pertain to the complexities inherently belonging to the domain of translation. The authors of the last two essays in this part draw our attention to the importance of phenomenological insights for both the establishment of the methodology applied in Translational Hermeneutics as well as the nature of the notion of translation equivalence.

The set opens with Brian O'Keeffe's paper Reading, Writing, and Translation in Gadamer's Hermeneutic Philosophy (pp. 15-45). The author of the article attempts to analyse Gadamer's essay Lesen ist wie Übersetzen, as juxtaposed against the backdrop of the philosopher's two well-known texts, namely Stimme und Sprache and Hören-Sehen-Lesen. According to O'Keeffe, a reading of the first essay offers its truest and most meaningful interpretation when confronted with the latter two papers. And, indeed, under close scrutiny what might be seen here are the reciprocity as well as circularity of the following three fundamental aspects of interpretation: reading, writing and translation. It has to be underlined that the author offers a very interesting and truly unique, or even innovative, reading of Gadamer's essays, paying close attention to the interpreting capacity of the so called "inner ear" and other bodily portals: the lips and the mouth, considered here an extension of the mind. By asserting that Übersetzen cannot "effectuate the Umsetzen that transposes readable writing into hearable sound-meaning" (p. 42), the author arrives at the inescapable conclusion that translation can only partially be compared to reading and has no role to play in the process of a 'transformation-back', where "reading relays writing to hearing" (p. 43).

In the article Understanding Husserl's Language of Essences: Hermeneutical Observations on Translation in Phenomenology (pp. 48-75), George Heffernan, by concentrating on the decisions that a translator dealing with such specialized texts as Husserl's Ideas on a Pure Phenomenology and Phenomenological Philosophy I has to make, in particular with relation to technical terms such as Wesenserschauungen, Wesenserkenntnisse or Wesensurteile, demonstrates the hermeneutical dimension of the dilemmas. As the author ably demonstrates, the terms might be rendered either substantively, with the aid of the word essence, or adjectivally, with the word eidetic. The selection of a particular equivalent is hugely influenced by the translator's understanding of both the terms involved and Husserl's philosophy; however, interestingly enough, the translator's decisions, 
in turn, exert a profound impact on the reader's understanding of the message of the target text (here, Husserl's transcendental philosophy). Aside from that, G. Heffernan also concludes that the final shape of a given translation might also be determined by the original author's authorization, earlier translations, as well as by "the consciousness of the phenomena of over-determination (consistency) and under-determination (ingenuity)" (p. 67). In the final section of the essay, by referring to etymological sources and the historical and philosophical background of given philosophical terms, the author also provides a handful of valuable comments on the German word Evidenz and its English translation as evidence.

Three papers discuss various aspects of the translation process, including philosophical, semiotic and rhetorical, as observed through the prism of hermeneutics. The focal issue of the article Dimensionen der Subjektivität beim Üersetzen by Radegundis Stolze (pp. 77-99) is subjectivity and its various dimensions in the translation process. The author analyses the following three types of subjects (the cognitive subject, the existential subject and the individual subject) and how they relate to the agency of the translator. R. Stolze rightly posits that all the three aspects are interlinked and incessantly depend upon one another in the translational process. Additionally, the author draws a clear line between so called traditional hermeneutics and its understanding of the role of the translator, and modern philosophical hermeneutics, along with its views on the conditions determining the translator's responsibilities. The article is fundamentally important because it raises the question of the intersubjectivity of all the agents participating in the translation process, and, as it seems, remains in agreement with what proponents of the latest theories within embodied cognition claim concerning the functioning of the mind.

The next paper discusses the interrelations between hermeneutics and semiotics. Lothar Černý, in his paper The Semiotic and Hermeneutic Aspects of Translation (pp. 101-117), attempts to identify the grounds on which translation phenomena could be analysed aside from the linguistic paradigm, searching for the common denominator within both Peirce's and Schleiermacher's views on the ways the human mind tackles the difference. As the author points out, "In the semiotic construction of cognition, knowledge and translation become fused in an indissoluble mental process" (p. 102). An even stronger assertion is found on the following page: “. . on the one hand, semiotics must negotiate a relation to hermeneutics, and on the other hand, because semiotics involves or encompasses acts of understanding, hermeneutics cannot be discussed without recourse to interpreting signs" (p. 103). Nonetheless, by drawing a detailed comparison between Peirce's and Schleiermacher's approaches, the author of the essay discerns many differences between the two thinkers, drawing attention to the status of significations as it relates to understanding. As he rightly observes: "While hermeneutical thinking focuses on the interpreting activity towards a given text-sign, the semiotic model sees the activity of the sign itself as ever-growing" (p. 115). Despite the significant differences in the 'interpreting response' towards, or out of, the sign, however, Černý is of the opinion that because the philosophy of signs shows certain implications of a hermeneutical nature, three disciplines whose representatives have not cooperated to a large ex- 
tent so far, namely hermeneutics, semiotics and Translation Studies, should definitely join forces to inquire into the mental processes of translation more effectively.

The rhetorical aspect of translation is discussed by Roberto Wu (p. 119-142), who attempts to analyse the notion of translation as juxtaposed with classical rhetoric, and to examine the most important principles of classical rhetoric "in reference to more contemporary philosophical movements, particularly phenomenology and hermeneutics" (p. 120). By analysing the interrelationship between the interpreter and the orator as depicted by Cicero, as well as the notion of ekphrasis, in the first part of the paper the author amply demonstrates how rhetoric is linked to translation: “. . in the rhetorical context, translation is not an end itself, but is subjected to the task of presenting a given subject vividly. This requires finding the right word, gesture, or expression" (p. 125). In the second part of Wu's essay, classical rhetoric is compared with hermeneutics. Despite obvious similarities between the two fields, here one may find even more differences, in particular as regards the status of written texts (p. 127). While it is generally hard to agree with the author that Gadamer's thought is built upon the premise that for philosophical hermeneutics "a written work is detached from the particular conditions in which it is originated. .." (ibid), quite a controversial claim, especially in the context of Gadamer's views on tradition and application, Wu rightly observes, though, that "a writer does not know the public to whom he or she is going to deliver the written work" (ibid) and that within hermeneutics, as opposed to classical rhetoric, the text is above all an autonomous entity. Finally, the author attempts to reconsider the relationship between rhetoric and translation. Wu is quite right in concluding that "rhetoric still matters for Translation Studies" (p. 135) and that translation ". . . is an activity that requires taking on the performativity of language and also its circumstantiality in order to enable the reader, or the audience, to see the subjects described as if they were present and vivid, right before their eyes" (p. 140).

Yet another set of aspects found within the paradigm of the hermeneutic approach to translation is presented by Mohammad Alavi in his article Social Dimensions of Hermeneutical Translation (pp. 143-176). The author aspires to prove that hermeneutical and social theories can complement each other in explaining the intricacies of the translational process. As Alavi says: "Although both theoretical structures work to a great extent with the question of understanding, TS scholars on either side have not yet come to an intellectual interaction. The ideas of this paper move in the direction of mutual communication. This paper is a first step toward such mutual communication" (p. 144). And, indeed, the author of the reviewed paper is right to observe that Translational Hermeneutics is lacking, or, perhaps, might seem to be lacking, in certain considerations of the role of social aspects inherent in the translation process. One has to generally corroborate the author's apt comment that while within the hermeneutical paradigm understanding is pondered in the context of the individual, what is taken into account within system theories are the society and its surrounding environment. At the same time, though, as it seems, such a distinction is oversimplified. For how else could the individual (within the hermeneutical paradigm) understand anything by not referring what they understand to the bigger part out of which details emerge? The issue at stake, then, is far more complex than initially presented in the article. By analysing 
Luhmann's theory of systems, the author puts the notion of understanding under close scrutiny and comes to the inescapable conclusion that understanding occurring at the psychic level and understanding emerging at the social level - two completely different moments in the translator's understanding of the text - are by no means the same. Nonetheless, even here at least some of the author's views are controversial and open to dispute, for instance, one cannot fully agree with the author's claim concerning the somewhat artificial division into psychic and communicative understanding during the translation process, in particular given the results of the latest cognitive studies on the theory of embodied simulation and the importance of intersubjectivity in the act of reading and writing. Besides, it seems, it is not always the case that "It is the target system that encourages the translator to select those utterances that correspond to earlier selections of utterances in the system and produce at the same time a structure of expectation for the ensuing communication events" (p. 170). For it is a well-known fact that the translator often resists the norms of the target system and opts for an innovative piece of writing with the overarching aim of pushing a given literary system forward (as noted within the polysystem theory). Despite those few critical remarks, though, one has to admit the text itself focuses on a very important aspect of the translator's activity, namely their relationship with the society and the environment in which they work, and furthermore, it has to be underlined that the author rightly calls for consideration of the enormous implications that certain social schemes have for the translator's understanding of the text.

The last two articles of this part deal with phenomenology and translation. The first one, by Katharina Hauptmann, titled Ansätze zur Untersuchung des Verstehens beim Dolmetschen und Übersetzen (pp. 177-212), is a valuable contribution to an ongoing discussion concerning the methods that are applied by translation scholars. Concentrating on the notion of understanding, the author of the paper seeks to suggest a way of applying the phenomenological method in order to inquire into how translators and interpreters understand. Apart from the discussion of the phenomenological method, introspection and retrospection in studying the process of understanding in translation and interpreting are also tackled. The article is a very important contribution to a current debate among translational hermeneutists concerning the status and role of methodology in researching into the hermeneutical approach to translation, in particular given the many negative remarks made by opponents of Translational Hermeneutics, who often criticize the subdiscipline for its lack of strict methodology.

Phenomenological implications for translation are brought to the fore in Simon Glynn's article titled Experience, Understanding, and the Translational Transformation of Reality (pp.213-234). As the author rightly observes: "The success of linguistic communication in general, and translation in particular, is dependent upon the veracity of our understanding of the meaning of concepts signified in or by a language or languages” (p. 213). Glynn asks in the opening section of his paper: "How are we to ensure that the articulation of experiences, thoughts, feelings and ideas in one language is commensurate with their articulation in another? How are we to ensure that the significance of what is being articulated in the one corresponds to what is being understood in the other?" (p. 214). And indeed, an answer to these questions, albeit necessarily a tentative one, is particularly 
important if one strives to discover what pertains to the intricacies of so called translation equivalence. The striking examples and astute observations provided in the text point to the impossibility of establishing translation correspondences in their traditional and strict sense. Furthermore, the author's essay offers an invitation to evaluate the status of human experience of the world and its relationship with so-called reality. The author's reflections upon the nature of understanding and communication deserve special attention, particularly given the view that "after the phenomenological reduction, it becomes clear that objects cannot be known to be more than bundles of perceptions" (p. 231).

The second set of papers is entitled Practical Approaches. This part of the reviewed monograph begins with two texts dealing with the use of hermeneutic and phenomenological methods in the translation classroom. John Wrae Stanley, in his article titled Verstehend Übersetzen: Hermeneutics, the Pragmatics of Translation, and Specialized Texts (pp. 237-270), discusses his own teaching method, whose main principles rest upon Heidegger's and Gadamer's philosophical hermeneutics. The author of the paper convincingly underlines the importance of understanding the source text before attempting to perform translation. The thesis concerning the notion of understanding might seem obvious to many; however, the majority of translation teachers will definitely agree with what the author claims about translation students' practices concerning the way they prepare for the translation process. Also, one has to agree with the author's conviction of the necessity for specializing: “. . . a young translator needs to delimit a few fields that (s)he wants to work in and do extensive internships in companies or organizations that are active in those fields" (p. 268). The hermeneutic method in translation didactics is also dealt with in the paper The Use of Hermeneutic Approach in Translation Classroom - Advantages from Translation Students' Point of View by Beata Piecychna (pp. 291-317), who analyses students' comments on the teaching method to which the author introduced the participants of the study in the academic year 2012-2013. The approach has been based on Radegundis Stolze's hermeneutic theory of translation as depicted in her monograph The Translator's Approach - Introduction to Translational Hermeneutics. Theory and Examples from Practice. Although the presented results are quite promising, they are by no means conclusive, and thus further research is needed to convincingly verify the impact of Stolze's approach - as opposed to other well known didactic approaches to translation - on the acquisition of translation competence.

A description of initial attempts to further develop phenomenological and hermeneutical methods which could be applied in both didactics and epistemological studies in Translation Studies and communication studies is presented by Romina Mählmann and John Wrae Stanley (pp. 271-290). The article, titled Phenomenology and Conversational Analysis in Communicology and Translatology - A Progress Report, concerns the verification of the Husserlian phenomenological method to be applied within the framework of role plays as deployed in the job interview. By reporting on an interaction workshop held at the University of Applied Sciences in Cologne in 2012, the authors attempt to discover to what extent the method might be of assistance in reflecting upon oneself while taking part in role plays. The article convincingly argues that the hermeneutical 
analysis held after the role play is of great help in understanding the subjects' interpretation of the whole procedure, as well as demonstrating the paramount role of cultural differences occurring in the act of understanding otherness.

The following two articles focus on an analysis of literary translation from a hermeneutic standpoint. The article titled Literarische Übersetzungskritik und Hermeneutik by Thomas J. C. Hüsgen (pp. 319-337) looks into selected examples of texts by Vergílio Ferreira, Agustina Bessa Luís, and Fernando Pessoa, translated from Portuguese into German by Georg Rudolf Lind. By concentrating on Gadamer's views on understanding, the notion of coherence as derived from Stolze's approach and the aspect of consistency in the translation process, the author of this thought provoking paper aspires to demonstrate to what extent the translator's "own profile" (p. 319) exerts a significant impact on the final versions of the examined texts, and whether the translational product fully renders the spirit of the source text. The second paper, by Claudia Tatasciore, titled Übersetzungshermeneutik und Kinderliteratur. Eine Fallstudie anhand der italienischen Übersetzungen von Ferenc Molnárs Die Jungen der Paulstraße (pp. 339-366), deals with the translation of children's literature, and without too gross a generalisation it can be noticed that it is one of very few papers in the literature discussing this type of translation from a hermeneutic perspective. That said, the article may set new paths for further research in the field of Children's Literature Translation Studies, or even constitute a good starting point for establishing a new subfield of Translational Hermeneutics in its own right, namely Children's Literature Translational Hermeneutics. The author of the paper, aside from underlining a multitude of factors which should be seriously considered by the translator, rightly claims that here the notion of dual readership is of paramount importance in the translation process, and that a hermeneutic approach, in particular the well-known notion of horizon, might be of great assistance in determining the motives behind the shape of a given translation, as well as behind the way the potential reader responds to the translational product, thus pointing to the under-researched question of intersubjectivity in the translation process.

Yet another issue discussed in this second set of essays deals with translation for the stage, a topic which has not yet been explored by staunch advocates of the hermeneutic approach to translation. Rainer Kohlmayer, in his article titled $\mathrm{Zu}$ Geschichte, Theorie und Praxis der Bühnenübersetzung. Am Beispiel von Corneilles Komödie Le Menteur (pp. 367-398), analyses Pierre Corneille's comedy Le menteur from 1643 in terms of the following five criteria (the "fünf Besonderheiten von Theatertexten"): orality, individual speech of dramatis personae, relations between persons, necessity of immediate audience comprehensibility, and theatricality/fictionality. The author of the paper attempts to compare four German translations of the comedy: the first one produced in 1767 by Goethe, the second one, from 1875, by Bing, the third one, from 1654, by Schiebelhuth, and the last one translated by Kohlmayer in 2005. Occasionally, though, the author reflects upon the 1989 English rendering of Corneille's comedy by Ranjit Bolt. By venturing a rather negative opinion about Schleiermacher's distinction between foreignisation and naturalization and its longlasting impact on 20th century translation theories in years to come, Kohlmayer, as it seems, quite 
rightly accentuates the importance of the orality of the source text as well as the need for properly considering the functionality of the translation product designed for theatrical performance.

The reviewed monograph offers a collection of very valuable essays, highly recommended for not only vocal proponents of the hermeneutic approach to translation, but also those interested in interdisciplinary attempts within the paradigm of Translation Studies. Furthermore, thanks to the articles that lie on the borderline between hermeneutics, phenomenology and Translation Studies, the volume should also find its readers among philosophers. Overall, the book is thought provoking, and this makes it a very useful reference in the current discussions of both the validity and indispensability of Translational Hermeneutics per se. Nevertheless, it should be noted that there still remains much work to be done to establish the status and position of Translational Hermeneutics within Translation Studies, both theoretically and methodologically, and also to fully appreciate and recognise not only the role of philosophical views on translation in constructing theories of translation, but also their unsurprisingly close connection with contemporary cognitive predictions as they relate to the nature of the translation process. The essays presented in the reviewed monograph contribute enormously and meaningfully to the translational literature by successfully depicting that translation, whether one accepts it as true or not, is entangled in the philosophical hermeneutic tradition, and that hermeneutists' ideas are, in turn, deeply rooted in the very nature of broadly defined translation: not only as a linguo-cultural transfer, but also as a way of communicating with and understanding the world.

\section{References}

Bronk, A. 1988. Rozumienie, dzieje, język. Filozoficzna hermeneutyka H.-G. Gadamera. Lublin: Redakcja Wydawnictw KUL.

Cercel, L. 2009. Übersetzen als hermeneutischer Prozess. Fritz Paepcke und die Grundlagen der Übersetzungswissenschaft. In: Larisa Cercel (ed.), Übersetzung und Hermeneutik - Traduction et herméneutique, 331-357. Bucarest: Zeta Books.

Cercel, L. 2013. Übersetzunghermeneutik. Historische und systematische Grundlegung. St. Ingbert: Röhrig.

Gadamer, H.-G. Kleine Schriften III. Idee und Sprache. Platon, Huseel, Heidegger. Tübingen: Mohr. Stolze, R. 1992. Hermeneutisches Übersetzen. Linguistische Kategorien des Verstehens und Formulierens beim Übersetzen. Tübingen: Narr.

Stolze, R. 2003. Hermeneutik und Translation. Tübingen: Narr.

Stolze, R. 2011. The Translator's Approach - Introduction to Translational Hermeneutics. Theory and Examples from Practice. Berlin: Frank \& Timme.

Stolze, R. 2015. Hermeneutische Übersetzungskompetenz. Grundlagen und Didaktik. Berlin: Frank \& Timme. 